\title{
Inflammatory bowel disease pada anjing yorkshire terrier
}

\author{
Arni Diana Fitri ${ }^{1 *}$, Deni Noviana ${ }^{1,2}$, Sitaria Fransiska Siallagan ${ }^{1,3}$, Nindya Dwi Utami ${ }^{1,3}$, Tri Isyani \\ Tunggadewi ${ }^{1}$, Rida Tiffarent ${ }^{1}$, Tina Magdalena ${ }^{4}$, Amalia Kuswardani ${ }^{4}$ \\ ${ }^{1}$ Rumah Sakit Hewan Pendidikan Fakultas Kedokteran Hewan, Institut Pertanian Bogor \\ ${ }^{2}$ Departemen Klinik Reproduksi dan Patologi Fakultas Kedokteran Hewan Institut Pertanian Bogor \\ ${ }^{3}$ Program Studi Ilmu Biomedis Hewan, Sekolah Pascasarjana, Fakultas Kedokteran Hewan, Institut Pertanian Bogor \\ ${ }^{4}$ Dokter Hewan Praktisi Swasta
}

\begin{abstract}
ABSTRAK: Inflamatory bowel disease (IBD) pada hewan kecil merupakan kasus penyakit saluran pencernaan kronis dengan penyebab belum diketahui secara pasti. Gejala klinis IBD mirip dengan penyakit pada saluran pencernaan lainnya, jarang ditemukan secara langsung dan pengobatan yang diberikan umumnya belum dapat menyelesaikan penyakit pasien. Kombinasi beberapa pemeriksaan penunjang sangat membantu dalam menetapkan diagnosa untuk pengobatan yang tepat. Seekor anjing Yorksire Terrier jantan umur 11 tahun dirujuk ke Rumah Sakit Hewan Pendidikan Fakultas Kedokteran Hewan Institut Pertanian Bogor untuk pemeriksaan ultrasonografi dan endoskopi. Keluhan utama berupa muntah sejak 2 minggu sebelumnya, muntah sebanyak 1-4 kali/hari dengan frekuensi semakin meningkat. Penanganan dokter yang merujuk berupa obat antibiotik dan anti muntah namun tidak ada perubahan. Hasil pemeriksaan darah menunjukkan peningkatan hemoglobin, hematokrit, monosit, neutrofil dan ureum darah, serta penurunan nilai trombosit, lipase dan total protein. Hasil radiografi menunjukkan akumulasi cairan di lambung, penebalan dinding lambung, akumulasi gas di usus kecil dan usus besar dan penebalan dinding usus serta tidak terlihat adanya tanda-tanda benda asing. Hasil endoskopi menunjukkan adanya oesofagitis, megaoesofagus pars thorakalis, perlukaan dinding oesofagus pars thorakalis, peradangan lambung dan tidak ditemukannya benda asing. Hasil pemeriksaan ultrasonografi menunjukkan adanya cholelithiasis, cholecystitis, gastritis dan penebalan signifikan pada bagian usus halus daerah duodenum proksimal. Terapi yang diberikan berupa pemasangan nasogastric tube (NGT) selama 72 jam untuk pemberian pakan cair dan obat simtomatis. Setelah NGT dilepas, pengobatan dilanjutkan hingga 7-14 hari, dan menunjukkan persembuhan setelah terapi dan pengobatan.

Kata kunci:

inflamatory bowel disease, gastritits, cholecystitis, Yorksire Terrier
\end{abstract}

\section{- PENDAHULUAN}

Inflammatory bowel disease (IBD) merupakan penyakit gastro intestinal kronis dengan penyebab belum diketahui secara pasti (Defarges 2016, Marks 2013, Mansfield 2011). Beberapa faktor penyebab diantaranya seperti Gastro Intestinal lymphoid tissue (GALD), kecacatan permiabilitas, genetik, iskemik, biokimia dan kelainan psikosomatik, infeksi dan agen parasit, alergen diare, dan efek negatif obat-obatan. Temuan terbaru menunjukkan penyebab lain berupa reaksi hipersensitifitas terhadap antigen contohnya makanan, bakteri, mukus, sel epitel di dalam lumen intestinal atau di mukosa (Defarges 2016,Neiger 2014). Lebih dari satu tipe reaksi hipersensitifitas terlibat sebagai penyebab IBD. Penyakit IBD bisa terjadi pada pencernaan bagian atas, usus kecil, usus besar atau disemua tempat secara bersamaan (Neiger 2014). Kejadian penyakit dapat berkepanjangan (persistent) maupun berselang atau intermittent (Mansfield 2011). Kejadian IBD jarang ditemukan secara langsung. Beberapa pemeriksaan penunjang diperlukan dalam menetapkan diagnosis IBD untuk pengobatan yang tepat.

\section{- KASUS}

Seekor anjing Yorkshire Terrier jantan umur 11 tahun dirujuk ke Rumah Sakit Hewan Pendidikan (RSHP) Fakultas Kedokteran Hewan (FKH) Institut Pertanian Bogor (IPB) untuk pemeriksaan penunjang ultrasonografi dan endoskopi. Pemilik membawa surat rujukan dari klinik hewan swasta. Anamnesis: Pasien sebelum datang ke RSHP FKH IPB muntah1-4 kali/hari sejak 2 minggu sebelumnya dengan frekuensi semakin meningkat. Pasien tidak mau makan dan lemas. Penanganan dokter hewan yang merujuk berupa obat antibiotik dan anti muntah (metoclopramide dan omeprazole) namun tidak ada perubahan. Pemeriksaan fisik: Pasien datang dalam keadaan diinfus dari klinik yang merujuk. Berat badan 2.9 $\mathrm{kg}$, temperatur rektum $38.0^{\circ} \mathrm{C}$, keadaan umum lemah, Body Condition score (BCS) 3/9, mukosa rose pucat kebiruan dan

Diterima: 07-02-2018 | Direvisi: 09-03-2018 | Disetujui: 12-03-2018 (C) 2018 CC-BY-SA.Ini adalah artikel Open Access yang didistribusikan berdasarkan ketentuan dari Creative Commons Attribution ShareAlike 4.0 International License (https://creativecommons.org/licenses/by-sa/4.0/). 
kiposis. Pemeriksaan penunjang: Pemeriksaandarah, radiologi dan endoskopi. Diagnosis: Inflammatory bowel disease. Prognosis: Fausta jika ditangani dengan tepat. Terapi: Pemasangan nasogastric tube (NGT) selama 72 jam. Pemilik diajarkan cara memberi makan dan obat melalui NGT. Obat yang diberikan bersifat simtomatis berdasarkan pemeriksaan penunjang yaitu Urdafak (Ondansetron untuk mengurangi muntah), CTM $(0.5 \mathrm{mg} / \mathrm{kg}$ PO q12h) dan Prednisolon (1-2 mg/kg PO q12h selama 2 minggu kemudian dikurangi dosis menjadi q24h selama 2 minggu) (Hall 2017). Antibiotik Trimetroprim dan Metronidazole masing-masing $15 \mathrm{mg} / \mathrm{kg}$ PO q12h selama 12 minggu.

\section{口 HASIL DAN PEMBAHASAN}

Hasil pemeriksaan hematologi dan kimia darah yang pertama dan pemeriksaan darah ulang terlihat peningkatan Hemoglobin, Hematokrit, Monosit, Neutrofil, Ureum, serta penurunan nilai pada Trombosit, Lipase dan Total Protein (Tabel 1). Tidak ada perubahan spesifik pada hematologi dan kimia darah pada kedua pemeriksaan.

Tabel 1. Hasil pemeriksaan darah lengkap dan kimia darah

\begin{tabular}{|l|l|c|c|c|}
\hline \multirow{2}{*}{ Parameter } & \multirow{2}{*}{ Satuan } & \multirow{2}{*}{ Normal } & \multicolumn{2}{c|}{ Pemeriksaan } \\
\cline { 4 - 5 } & & & Awal & Pascaterapi \\
\hline Hemoglobin & $\mathrm{g} / \mathrm{dL}$ & $12.0-18.0$ & 21.1 & 19.5 \\
Eritrosit & $10^{6} / \mathrm{mm}^{3}$ & $5.5-8.5$ & 8.34 & 7.38 \\
Hematokrit & $\%$ & $37.0-55.5$ & 57 & 50.7 \\
Trombosit & $10^{3} / \mathrm{mm}^{3}$ & $200-500$ & 188 & 248 \\
Leukosit & $10^{3} / \mathrm{mm}^{3}$ & $6.0-17.0$ & 8.6 & 19.5 \\
Basofil & $\%$ & $0-1$ & 0 & 0 \\
Eosinofil & $\%$ & $2-10$ & 0 & 0.3 \\
Netrofil & $\%$ & $60-77$ & - & 79.5 \\
Net. batang & $\%$ & $0-3$ & 0 & - \\
Net. segmen & $\%$ & - & 82 & - \\
Limfosit & $\%$ & $12-30$ & 15 & 8.8 \\
Monosit & $\%$ & $3-10$ & 3 & 11.4 \\
Total protein & $\mathrm{g} / \mathrm{dL}$ & $5.1-7.8$ & 7.10 & - \\
Albumin & $\mathrm{g} / \mathrm{dL}$ & $2.6-4.3$ & 2.68 & 2.8 \\
Globulin & $\mathrm{g} / \mathrm{dL}$ & $2.3-4.6$ & 4.42 & - \\
ASAT/SGOT & $\mathrm{U} / \mathrm{L}$ & $5-55$ & 25 & 20.4 \\
ALAT/SGPT & $\mathrm{U} / \mathrm{L}$ & $5-60$ & 10 & 13.0 \\
Alkalin fosfat & $\mathrm{U} / \mathrm{L}$ & $10-150$ & 44 & 27.0 \\
Ureum & $\mathrm{mg} / \mathrm{dL}$ & $7-27$ & 44 & 9.2 \\
Kreatinin & $\mathrm{mg} / \mathrm{dL}$ & $0.4-1.8$ & 1.2 & 0.9 \\
CPK & $\mathrm{U} / \mathrm{L}$ & $10-200$ & - & 90 \\
Amilase & $\mathrm{U} / \mathrm{L}$ & $500-1500$ & - & 810 \\
Lipase & $\mathrm{U} / \mathrm{L}$ & $100-500$ & - & 68 \\
Natrium & $\mathrm{mEq} / \mathrm{L}$ & $141-156$ & - & 148 \\
Kalium & $\mathrm{mEq} / \mathrm{L}$ & $4.0-5.6$ & - & 4.6 \\
Klorida & $\mathrm{mEq} / \mathrm{L}$ & $105-115$ & - & 111 \\
\hline
\end{tabular}

Radiografi menunjukkan akumulasi cairan di lambung, penebalan dinding lambung (Gambar 1a). Terdapat akumulasi gas di usus kecil dan usus besar dan dinding usus lebih radioopak dan terlihat lebih tebal namun tidak ditemukan adanya benda asing. Endoskopi menunjukkan esofagitis, megaesofagus pars thorakalis, perlukaan pada dinding esofagus pars thorakalis, gastritis dan tidak ada benda asing (Gambar 1b). Ultrasonografi menunjukkan cholelithiasis, cholecystitis, gastritis dan penebalan usus halus daerah duodenum proksimal (Gambar 1c-e).

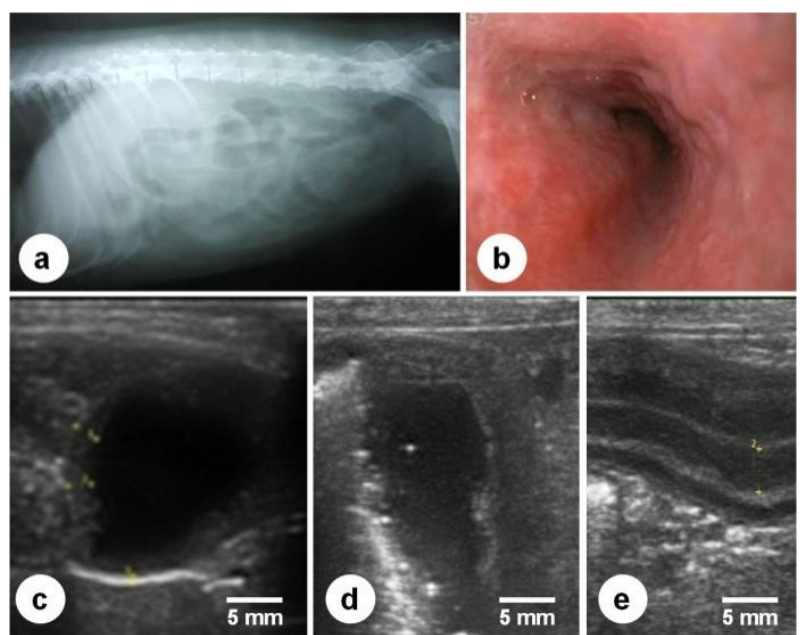

Gambar1. Radiologi dan endoskopi: (a) radiografi, (b) endoskopi, ultrasonografi empedu (c), lambung (d) dan usus (e)

Kondisi tubuh pasien tampak membaik setelah berlangsung 4 hari terapi dan pengobatan. NGT kemudian dilepas dan pasien mulai mau makan secara spontan tanpa mengalami muntah. Pengobatan kemudian dilanjutkan hingga 5-7 hari.

\section{- SIMPULAN}

Diagnosa inflammatory bowel disease pada anjing yorkshire terrier dapat diteguhkan dengan menggunakan ultrasonografi dan endoskopi. Ultrasonografi menunjukkan adanya peradangan dan batu pada kantung empedu, peradangan pada lambung, dan peradangan hebat pada usus halus. Sedangkan endoskopi menunjukan adanya peradangan pada esofagus, distensi esofagus, dan peradangan pada lambung.

\section{- INFORMASI PENULIS}

Penulis untuk korespondesi

*ADF:arnidianafitri@gmail.com

Rumah Sakit Hewan Pendidikan, Fakultas Kedokteran Hewan, Institut Pertanian Bogor, Jln Agatis Kampus IPB Dramaga, 16680

\section{TERIMA KASIH}

Terima kasih kepada PT MUM yang telah memfasilitasi peralatan USG di RSHP FKH IPB untuk diagnosa penunjang pada kasus ini.

\section{- PUSTAKA ACUAN}

Defarges A. 2016. Inflammatory bowel disease in small animals. Merck veteterinary manual. Merck Sharp \& Dohme Corp.: USA

Hall EJ. 2017. How I treat inflammatory bowel disease. North American Veterinary Confrence. Orlando (Florida, US). Jan 13-27, 2017

Mansfield C. 2011. Diagnosis and management of canine inflammatory bowel disease. Small Animal Veterinary Congress WSAVA. Jeju (Korea). Oct 14-17. 2011.

Marks SL. 2013. How I treatdogs with inflammatory bowel disease. Southern European Veterinary Conference and Congreso Nacional AVEPA. Barcelona (Spain). Oct 17-19, 2013

Neiger R. 2014. Inflammatory bowel disease, pathogenesis, diagnosis and treatment. Southern European Veterinary Conference and Congreso Nacional AVEPA. Barcelona (Spain). Oct 16-18, 2014. 